\title{
Communication
}

[Comunicação]

\section{Occurrence of Sarcopromusca pruna (Diptera) in Southern Brazil as a vector of Dermatobia hominis (Diptera) eggs}

\author{
[Ocorrência de Sarcopromusca pruna (Diptera) no sul do Brasil como vetor de ovos de Dermatobia hominis \\ (Diptera)]

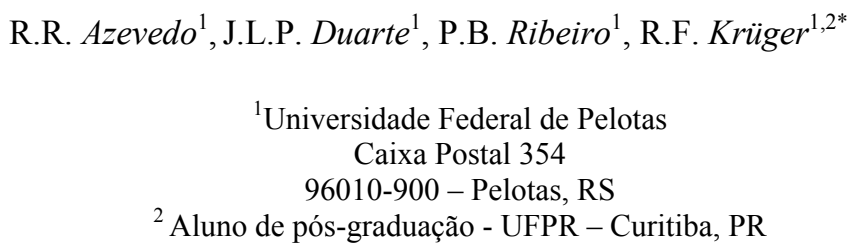

Dermatobia hominis (Linneaus Jr., 1781) (Diptera: Oestridae) is found from South Mexico to Argentina. In Brazil, it is most frequently found in Bahia, Rio de Janeiro, São Paulo, Espírito Santo, Goiás and Minas Gerais States (Maia and Guimarães, 1985). It is among the most important ectoparasites of medical and veterinary importance in Latin America. Its economic damage to livestock is primarily decrease of milk and meat production, but also includes retarded growth, pre-disposition to several illnesses, and partial or total damage to the leather, used by the shoe industry (Gomes et al., 1998). They occur because its larvae, popularly known as berne, cause nodular cutaneous myiasis.

One of the unique characteristics of this species is the capture of other insects and subsequent oviposition on their abdomens, turning them into phoretic vectors of its eggs. In this context, the probability of preferential vectors of egg of $D$. hominis was described by Creighton and Neel (1952). They described the characteristics necessary of vectors of diurnal activity as being smaller size than the adult human bot-fly, moderate locomotive activity, and zoophilous habits.

Several hematophagous flies with symbovine habits vary in frequency and importance from area to area as vectors of Dermatobia eggs.
Sarcopromusca pruna (Shannon and Del Ponte, 1926) (Diptera, Muscidae) is a species with zoophilous habits with a short biological cycle. The adults are lapping flies that feed on wounds caused by the blood feeding activity of Stomoxys calcitrans (L., 1758) (Diptera, Muscidae) or other hematophagous insects. They persist with this behaviour and are not disturbed even by animal movements or human presence. The larvae develop in bovine and equine excrement (Pedroso-de-Paiva, 1996). For this reason, in Latin America, this fly is suspected of being an important phoretic vector of $D$. hominis eggs (Neel et al., 1955; Koone and Banegas, 1959; Lombardero and Fontana, 1968; Silva et al., 1989), with geographic distribution similar to the bot-fly (Guimarães and Papavero, 1999; Nihei, 2005). In Bahia, S. pruna was the main vector of D. hominis eggs (Silva et al., 1989), and in Mato Grosso do Sul it played an important role in botfly epidemiology (Gomes et al., 1998).

A female specimen of $S$. pruna was captured in a Malaise trap that had been installed in the municipal district of Arroio Grande, about $12 \mathrm{~km}$ from the urban center, in a livestock area with vegetation characteristic of the south of the state. The collection was made on January 24, 2003 as part of a larger sampling of Diptera from Southern Brazil. Following the identification of the specimen, using the key proposed by Carvalho et al. (2002) and Nihei (2005), the

Recebido em 28 de março de 2006

Aceito em 25 de setembro de 2007

*Corresponding author (autor para correspondência)

E-mail: rfkruger1974@yahoo.com.br 


\section{Occurrence of Sarcopromusca pruna...}

presence of 18 eggs of $D$. hominis was verified in the lateral-ventral portion of the fly abdomen of the fly (Fig. 1A). The ovipositional mass containing those eggs resembled a bunch of bananas (Fig. 1A). Those eggs, at the moment of oviposition, came out soaked in a substance that quickly solidified in contact with the air. They are similar in appearance to a human finger, and at the distal extremity the operculum resemble a nail (Fig. 1B).
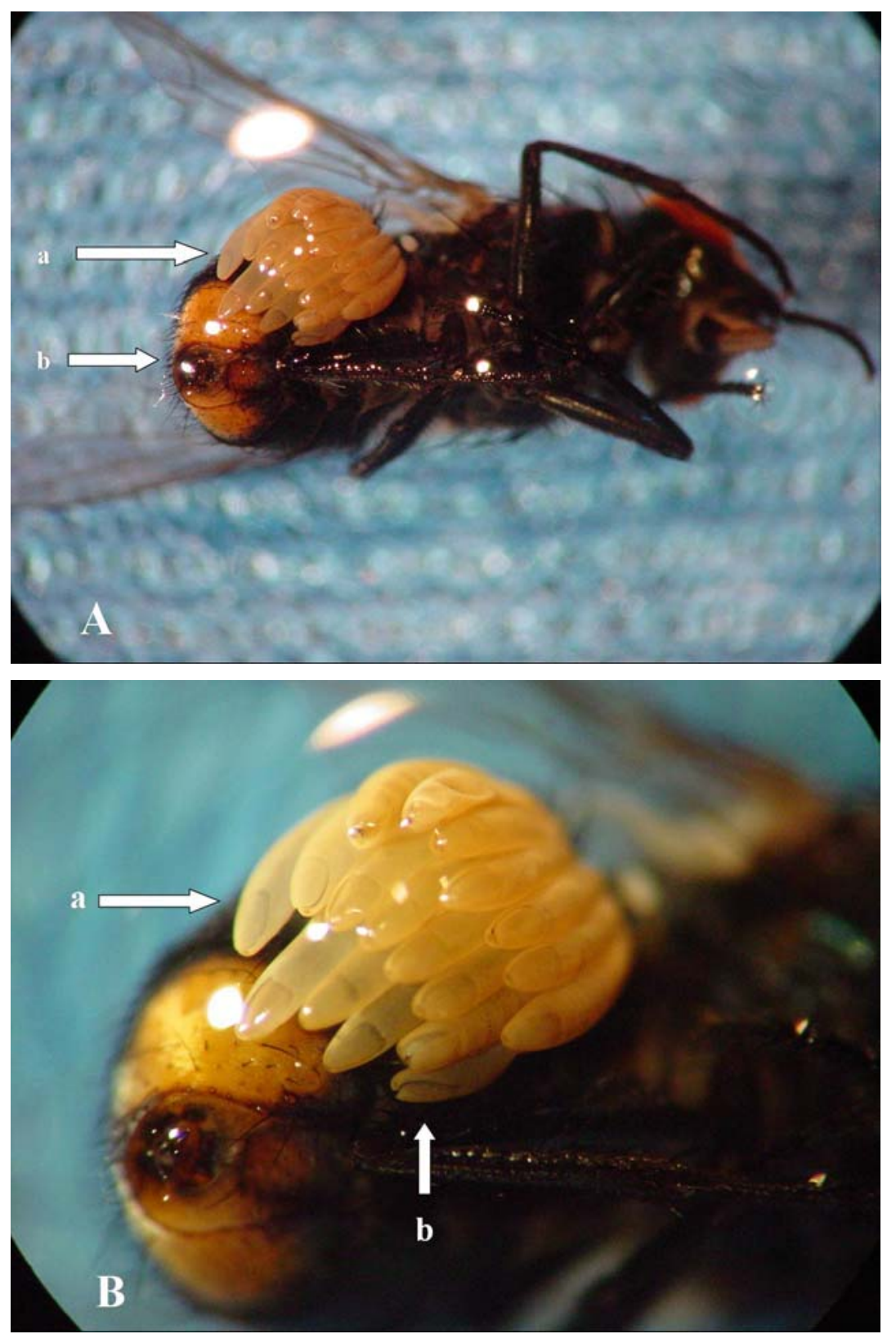

Figure 1. Ventral portion of Sarcopromusca pruna. A) general portion, a: ovipositional mass containing these eggs appeared like a bunch of bananas; b: terminalia. B) approach of the ventral portion, a: egg already without larva and is similar in appearance to a human finger, and at the distal extremity the operculum appears like a nail; b: larva hatches. 
There are no preferences relative to side of the oviposition of $D$. hominis on $S$. pruna. It can happen on each or both sides simultaneously in the same specimen, with a direct relationship between the size of the abdomen and the number of the eggs (Silva et al., 1989).

There were no previous reports of $S$. pruna being a vector of $D$. hominis eggs in Southern Brazil. Previously, vectoring of $D$. hominis in Southern Brazil had been reported for Fannia tumidifemur Stein, 1911 (Diptera, Fanniidae) in Paraná (Pinto et al., 2002), Fannia heydenii (Weidemann, 1830), Musca domestica L., 1758 (Muscidae) and Morellia humeralis (Stein, 1918) (Muscidae) in Santa Catarina (Paloshi et al., 1991) and $S$. calcitrans, $M$. domestica and Fannia punctipennis Albuquerque, 1954 in Rio Grande do Sul (Ribeiro et al., 1985; Brum et al., 1998).

The collected material has been preserved in $70 \%$ alcohol and it is deposited in the Entomological Collection of the Departamento de Microbiologia e Parasitologia (CDEMPUFPel).

Keywords: Dermatobia hominis, Sarcopromusca pruna, Muscidae, Oestridae

\section{RESUMO}

Relata-se a ocorrência de Sarcopromusca pruna como vetor biológico de Dermatobia hominis no sul do Brasil. $O$ diptero foi capturado em Janeiro de 2003 em armadilha Malaise, permanentemente instalada desde Julho de 2002, como parte de um estudo de diversidade de Muscoidea no bioma Campos Sulinos, extremo sul do Rio Grande do Sul. O espécime estava carreando 18 ovos de D. hominis na porção látero-ventral direita do abdome.

Palavras-chave: Dermatobia hominis, Sarcopromusca pruna, Muscidae, Oestridae

\section{ACKNOWLEDGMENTS}

To Dr. Philip J. Scholl (University of Nebraska) for suggestions and for his help in the English version. To PBIC/CNPq for the grants to JLPD and CAPES for the grants to RFK.

\section{REFERENCES}

BRUM, J.G.W.; VIANNA, E.S.S.; COSTA, P.R.P. et al. Sinanthropy and seasonal incidence of Fannia punctipennis (Diptera: Fanniidae) em Pelotas, Rio Grande do Sul, Brazil. Rev. Bras. Parasitol. Vet., v.7, p.149-150, 1998.

CARVALHO, C.J.B; MOURA, M.O.; RIBEIRO, P.B. Chave para adultos de dípteros (Muscidae, Fanniidae, Anthomyiidae) associados ao ambiente urbano no Brasil. Rev. Bras. Entomol., v.46, p.107-114, 2002.

CREIGHTON, J.T.; NEEL, W.W. Biologia y combate del torsalo o nuche, Dermatobia hominis (L. Jr.): Reseña bibliográfica. Turrialba, v.2, p.59-65, 1952

GOMES, A.; HONER, M.R.; KOLLER, W.W. et al. Vetores de ovos de Dermatobia hominis (L. Jr., 1781) (Diptera: Cuterebridae) na região de Cerrados do Mato Grosso do Sul, Brasil. Rev. Bras. Parasitol. Vet., v.7, p.37-40, 1998.

GUIMARÃES, J.H.; PAPAVERO, N. (Eds). Myiasis in Man and Animals in the Neotropical Region, Bibliographic Database. São Paulo: Editora Plêiade, 1999. 308p.

LOMBARDERO, O.J.; FONTANA, B.A.J. La "ura" (Dermatobia hominis) en la Provincia de Formosa. Gac. Vet., v.30, p.297-306, 1968.
MAIA, A.A.M.; GUIMARÃES, M.P. Berne: Susceptibilidade de bovinos, distribuição no hospedeiro, associação com outras miíases e abscessos. Arq. Bras. Med. Vet. Zoot. v.37, p.461-467, 1985.

NEEL, W.W.; URBINA, O.; VIALE, E. et al. Ciclo biológico del torsálo (Dermatobia hominis, L. Jr., 1781) en Turrialba. Turrialba, v.5, p.91-104, 1955.

NIHEI, S.S. A review of the Neotropical genus Sarcopromusca Townsend (Diptera: Muscidae) with a key to species and a redescription of $S$. sarcophagina (Wulp). Zootaxa, v.1004, p.51-64, 2005.

PALOSHI, C.G.; RAMOS, C.I.; SOUZA, A.P. et al. Vetores de ovos de Dermatobia hominis no Planalto Catarinense. Pesq. Agropec. Bras., v.26, p.1879-1883, 1991.

PEDROSO-DE-PAIVA, D. Aspectos da biologia de adultos de Sarcopromusca pruna (Shannon \& Del Ponte, 1926) (Diptera:Muscidae). Rev. Bras. Biol., v.56, p.183-190, 1996.

PINTO, S.B.; ROCHADELLI, R.; SOCCOL, V.T. et al. Bioecologia de Dermatobia hominis (Linnaeus Jr., 1781) em Palotina, Paraná, Brasil. Cienc. Rural, v.32, p.821-827, 2002.

RIBEIRO, P.B.; OLIVEIRA, C.M.B.; COSTA, P.R.P. et al. Foréticos da Dermatobia hominis (L. Jr., 1781) (Diptera:Cuterebridae), no Rio Grande do Sul, Brasil. Arq. Bras. Med. Vet. Zoot., v.37, p.507-509, 1985.

SILVA, A.A.J.; SMITH, D.H.; BARBOSA, S.A.J.S. Sarcopromusca pruna (Diptera, Muscidae) as an egg transport host of Dermatobia hominis (Diptera: Cuterebridae) in the Cacau Region of Bahia, Brazil. Mem. Inst. Oswaldo Cruz, v.84, supl.IV, p.491-497, 1989. 